\title{
Stability Investigation of Clayey Soil using Shredded Tyre and Lime
}

\author{
Sumit Kumar ${ }^{1}$, J.P. Singh ${ }^{2}$ and M.K. Mishra ${ }^{3}$ \\ ${ }^{1}$ Research Scholar, Department of Civil Engineering, BIT Sindri, \\ Dhanbad, India \\ ${ }^{2}$ Associate Professor, Department of Civil Engineering, BIT Sindri, \\ Dhanbad, India \\ ${ }^{3}$ Assistant Professor, Department of Chemistry, BIT Sindri, \\ Dhanbad, India
}

\begin{abstract}
The engineering strength properties of expensive soils (clayey soil) such as compaction characteristics and bearing capacity can be improved by stabilization process of the soil. These properties can be improved by controlled compaction using the mechanical equipment's or by addition of suitable admixtures like cement, fly ash, lime or by reinforcing the soil with shredded tyre, crumb rubber, plastic waste etc. But in recent years, tyre chips are used very widely because these are economical than the other admixtures and are abundantly available in the market, so in this research paper shredded tyre has been used to improve the various strength properties of natural soil. The objective of this research paper is to investigate the strength properties of natural clayey soil reinforced with different percentages of lime treated shredded tyre by the weight of soil and fixed percentage of lime as a binding material. A series of Standard Proctor Tests, Unconfined Compressive strength (UCS) tests and California Bearing Ratio (CBR) tests are conducted on both natural soil and reinforced soil with varying percentages of lime treated shredded Tyre $(4 \%, 8 \%, 12 \%$ and $16 \%)$ by weight and fixed percentage of Lime $(10 \%)$. It is observed from this study that the optimum values of MDD, UCS and CBR tests are obtained at $12 \%$ of shredded tyre and $10 \%$ of lime for a given clayey soil.
\end{abstract}

Keywords: Lime, Shredded tyre, Clayey Soil, MDD UCS, CBR Values

\section{Introduction}

As we know a significant portion of total land area is covered by expensive soils in our country India. Expansive soils such as clays are known to be a light weight aggregate with a rounded particles having line of porous. These soils are prone to changes in large volume and are directly related to the change in water content. Expansive soils expand when water is added to them i.e. swelling and shrink when they dry out. During monsoon or summer seasons, these soils will swell or shrink due to which change in volume takes place which may cause the differential settlement in the foundations. The pavements which are laid under expansive soils are easily prone to develop cracks and path holes due to inability of these soils to resistant heavy loads and there by reduces the durability of the pavements.

Soil stabilization refers to the process of changing soil properties to improve strength and durability of soil. There are many techniques for soil stabilization, including compaction, dewatering and by adding some reinforcement materials like shredded tire and lime to the soil. Stability of soil is our main concern before constructing any type of structure. As we know that the load of any structure is transferred to the soil and it is distributed over the soil particles. The prime objective of soil stabilization is to improve the California Bearing Ratio of in-situ soil and to increase the load carrying capacity of soil. In the present investigation, shredded tyre from waste tyre has been chosen as the reinforcement material because it can improve the bearing capacity of soil to a large extent and is available in the market at very low cost ,also its bad impact on environment can be reduced when we use it in the soil stabilization. Lime as a binding material is used which will be mixed into the soil to improve the stability of soil.

The term modification implies a minor change in the properties of soil, while stabilization means that the engineering properties of the soil have been changed enough to allow field construction to take place.

This thesis present the effect of lime treated shredded tyre on engineering properties of clayey soil. Soil 
engineering tests like Atterberg limits, OMC-MDD, UCS and CBR test were conducted on natural soil and soil-lime-shredded tyre mixture.

\section{Materials Used}

The materials used for the stabilization of soil are given in the following table.

Table-1 Materials used

\begin{tabular}{|l|l|c|}
\hline S.N. & Name of Material & Source of Material \\
\hline 1 & Soil & BIT , Sindri Campus \\
\hline 2 & Shredded tyre & $\begin{array}{c}\text { Ashok Traders } \\
\text { Mumbai }\end{array}$ \\
\hline 3 & Lime & Local Market \\
\hline 4 & Distilled Water & \\
\hline
\end{tabular}

\section{A. SOIL}

The Soil sample used in this study has been taken from the BIT Sindri Campus to a depth of 2 to 4 feet below the ground surface by open excavation.

Table-2 Properties of natural soil

\begin{tabular}{|l|l|l|}
\hline \multicolumn{1}{|c|}{ S.N. } & \multicolumn{1}{|c|}{ Parameters } & \multicolumn{1}{c|}{ Values } \\
\hline 1. & Specific Gravity & 2.56 \\
\hline 2. & Liquid Limit & $39.30 \%$ \\
\hline 3. & Plastic Limit & $20.95 \%$ \\
\hline 4. & Shrinkage limit & $15.21 \%$ \\
\hline 5. & Plasticity index & $18.35 \%$ \\
\hline 6. & Shrinkage index & $5.74 \%$ \\
\hline 7. & OMC & $16.13 \%$ \\
\hline 8. & MDD & $1.750 \mathrm{~g} / \mathrm{cc}^{2}$ \\
\hline 9. & UCS & $3.35 \mathrm{~kg} / \mathrm{cm}^{2}$ \\
\hline 10. & Soaked CBR & $1.93 \%$ \\
\hline 11. & Un-soaked CBR & $4.02 \%$ \\
\hline 12. & Percentage finer than & $64.7 \%$ \\
\hline 13. & 75 micron (clay +silt) & \\
\hline & Percentage of Clay & $14.85 \%$ \\
\hline
\end{tabular}

\section{B. SHREDDED TYRE}

Shredded tyre is very thin pieces of scrap tyres which are being produced and accumulated in large volumes causing an increasing threat to the environment. In order to eliminate the negative effect of these depositions and in terms of sustainable development there is great interest in the recycling of these non hazardous solid wastes. Tire wastes can be used light weight material either in the form of powder, chips, shredded and as a whole. Many works regarding the use of scrap tires in geotechnical application have been done especially as embankment materials. The reuse application for tire is removing of metal reinforcing and shredding until the desired materials are achieved.

\section{LIME}

Lime is the burned byproduct of limestone. Lime is the oldest developed material used for construction works; it is being used by human for more than 2000 years. Also, Lime has been used by Romans for road construction. Stabilization of soils with lime is widely used in various construction works such as foundation base, highways, railways, airports, embankments, slope protection, canal lining etc. Lime is used vastly for stabilizing soil as it is economic, easy construction as well as technology is simple that gives an attraction for the engineers.

\section{Sample Preparation}

\subsection{Treatment of shredded tyre with lime}

To make the tyre surface rougher it has been treated with lime. First of all the shredded tyre has immersed in the lime water solution for 24 hours, after 24 hours the shredded tyre has kept out from the solution and spread on the floor for 2 to 3 days for natural drying. This lime treated shredded tyre is used as a reinforcing material to improve the various properties of natural clayey soil.

\subsection{Sample preparation for testing of soil}

The natural soil has been replaced by varying percentage of lime treated shredded tyre $(4 \%, 8 \%, 12 \%, 16 \%)$ by weight and fixed percentage of lime (10\%) as given below in the table. 3

Table-3 Sample preparation

\begin{tabular}{|l|l|l|l|l|}
\hline S.NO. & Nomenclature & $\begin{array}{l}\text { Soil } \\
(\%)\end{array}$ & $\begin{array}{l}\text { Fixed } \\
\text { Lime } \\
(\boldsymbol{\%})\end{array}$ & $\begin{array}{l}\text { Lime } \\
\text { treated } \\
\text { shredded } \\
\text { tyre }(\%)\end{array}$ \\
\hline 1 & SL0T0 & 100 & 0 & 0 \\
\hline 2 & SL10T4 & 86 & \multirow{3}{*}{10} & 4 \\
\hline 3 & SL10T8 & 82 & 8 \\
\hline 4 & SL10T12 & 78 & & 12 \\
\hline 5 & SL10T16 & 74 & & 16 \\
\hline
\end{tabular}

\section{Experimental Section}

A series of laboratory tests were performed on both natural soils and reinforced soil with shredded tyre and lime. The list of experiments conducted in the laboratory as per IS codes are given below.

\subsection{Standard Proctor Test}

From the standard proctor compaction test, percentage of water content and maximum dry density relationship of the given soil reinforced with different percentages of lime treated shredded tyre $(4 \%, 8 \%, 12 \%$ and $16 \%)$ and mixed with lime at a 
fixed percentage of $10 \%$ is obtained. A series of Standard Proctor Compaction Tests are performed on reinforced soil with shredded tyre and lime as per (IS-2720 Part-VII) code procedure. Shredded Tyre, lime and natural soil are mixed thoroughly until the mix becomes uniform and homogeneous. As per Standard Proctor Compaction Test procedure, reinforced soil sample is filled in the compaction mould by three equal layers and each layer is being given with 25 blows of $2.6 \mathrm{~kg}$ hammer from height of $30 \mathrm{~cm}$. The test as per the mentioned procedure is performed for all reinforced soil specimens containing different percentages of shredded tyre and fixed percentage of lime.

\subsection{Unconfined Compressive Strength Test}

This is a special case of the tri-axial test in which confining or cell pressure is zero. This test is an untrained test or quick test and is often used to determine the in situ strength of soft, saturated fine grained soil deposits. The test was carried out on clayey soil as per procedure given in IS: 2720 Part 10-1991. UCS test was done using unconfined compression testing machine.

\subsection{California Bearing Ratio (CBR) Test}

CBR is a penetration test for evaluation of the bearing capacity of natural soil, sub-grades and base courses beneath new carriage way. CBR values are usually calculated for penetration of 2.5 and $5.0 \mathrm{~mm}$. Corresponding to the penetration value at which the CBR values is desired, corrected load value shall be taken from the load penetration curve and the CBR value is calculated. CBR test was carried out as per procedure given in IS: 2720 Part 16-1987. The soaked and un-soaked CBR test has been done on the natural and reinforced soil sample. At first, required quantity of shredded tyre and lime are blended with $5 \mathrm{~kg}$ of dry natural soil. After adding tyre and lime, they are mixed thoroughly until homogeneous mix and uniformity is obtained. After reinforced soil sample is prepared, the sample is filled in the CBR mould with three equal layers and each layer is being given by 56 numbers of blows by a $2.6 \mathrm{~kg}$ rammer for light static compaction. Load required for penetrating the piston through the reinforced soil sample up to $10 \mathrm{~mm}$ penetration depths is recorded. From the loads obtained, CBR values for all reinforced soil samples are determined and the results are presented in Results and Discussion section.

\section{Result and Discussion}

\subsection{Test Results of Stabilized Soil}

Results for reinforced soil sample with varying percentages of lime treated shredded tyre (LTST)
$(4 \%, 8 \%, 12 \%$ and $16 \%)$ by weight and constant percentage of lime $(10 \%)$ are presented in details. A series of standard proctor compaction tests, unconfined compressive strength test and California bearing ratio test are performed on reinforced soil with varying percentages of lime treated shredded tyre and constant percentage of lime and the corresponding results are shown below in tabulated form.

\subsubsection{Standard Proctor Test}

Table-4 Test Result of OMC-MDD of reinforced soil

\begin{tabular}{|c|c|c|c|c|c|}
\hline Nomenclature & $\begin{array}{l}\text { Soil } \\
(\%)\end{array}$ & $\begin{array}{c}\text { Lime } \\
\text { fixed } \\
(\%)\end{array}$ & $\begin{array}{c}\text { LTST } \\
(\%)\end{array}$ & $\begin{array}{c}\text { OMC } \\
(\%)\end{array}$ & $\begin{array}{l}\text { MDD } \\
(\mathrm{g} / \mathrm{cc})\end{array}$ \\
\hline SLOT0 & 100 & 0 & 0 & 16.13 & 1.75 \\
\hline SL10T4 & 86 & \multirow{4}{*}{10} & 4 & 15.50 & 1.80 \\
\hline SL10T8 & 82 & & 8 & 14.85 & 1.85 \\
\hline SL10T12 & 78 & & 12 & 14.07 & 1.93 \\
\hline \begin{tabular}{|l} 
SL10T16 \\
\end{tabular} & 74 & & 16 & 15.68 & 1.79 \\
\hline
\end{tabular}

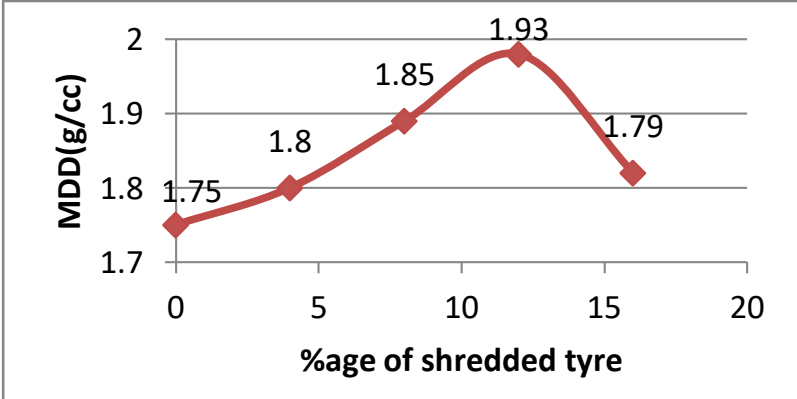

Fig- 1 Variation of MDD with different \%age of shredded tyre

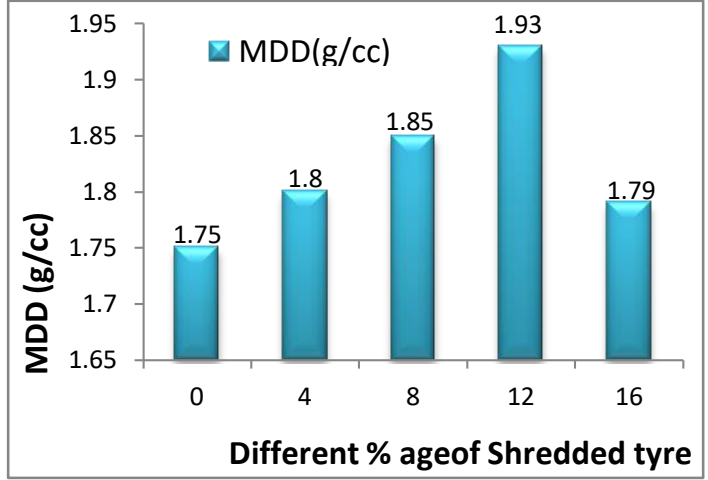

Fig-2 Bar chart variation of MDD with different \%age of shredded tyre

Based on the data in Table 4 and from Fig.1\&2 from the standard proctor test, it is find out that Maximum Dry Density (MDD) of natural soil is observed to be $1.75 \mathrm{~g} / \mathrm{cc}$ and is being increased to $1.93 \mathrm{~g} / \mathrm{cc}$ with 
increment of about $10.28 \%$ compared to MDD of natural soil at $12 \%$ of shredded tyre and $10 \%$ of lime.

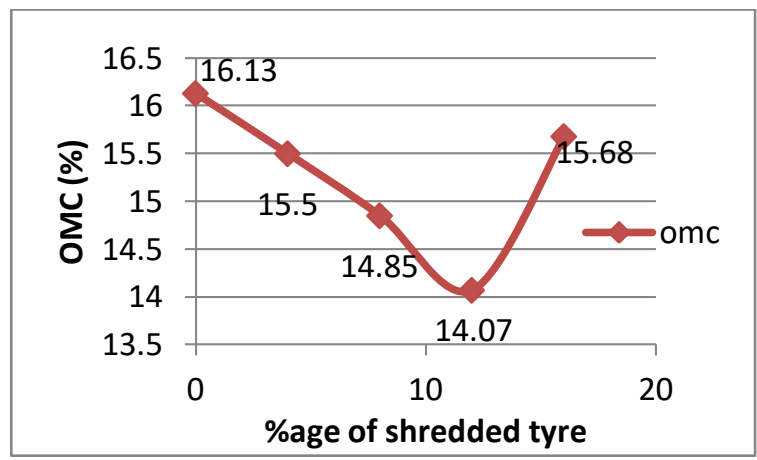

Fig-3 Variation of OMC with different \%age of shredded tyre

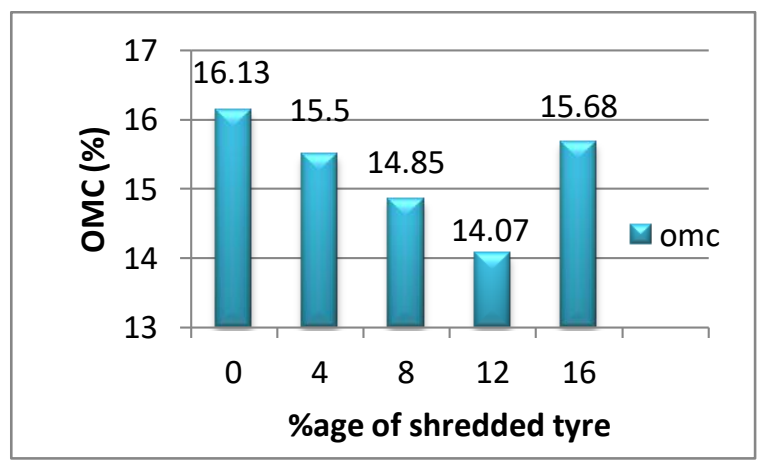

Fig.-4 Bar chart variation of OMC with different \%age of shredded tyre

From the above figure we find out the OMC of natural soil is $16.13 \%$ and after mixing the shredded tyre $(12 \%)$ and lime $(10 \%)$ the OMC value changed to $14.07 \%$

\subsubsection{Unconfined compressive strength (UCS) test}

The results obtained from laboratory tests for UCS mixed with different percentage of shredded tyre and fix percentage of lime has been tabulated below.

Table-5 UCS Test results of reinforced soil

\begin{tabular}{|c|c|c|c|c|}
\hline Nomenclature & $\begin{array}{l}\text { Soil } \\
(\%)\end{array}$ & $\begin{array}{l}\text { Fixed } \\
\text { Lime } \\
(\%)\end{array}$ & $\begin{array}{c}\text { LTST } \\
(\%)\end{array}$ & $\begin{array}{c}\mathrm{UCS} \\
\left(\mathrm{kg} / \mathrm{cm}^{2}\right)\end{array}$ \\
\hline SL0T0 & 100.00 & 0 & 0 & 3.35 \\
\hline SL10T4 & 86 & \multirow{4}{*}{10} & 4 & 4.27 \\
\hline SL10T8 & 82 & & 8 & 4.98 \\
\hline SL10T12 & 78 & & 12 & 5.63 \\
\hline SL10T16 & 74 & & 16 & 4.17 \\
\hline
\end{tabular}

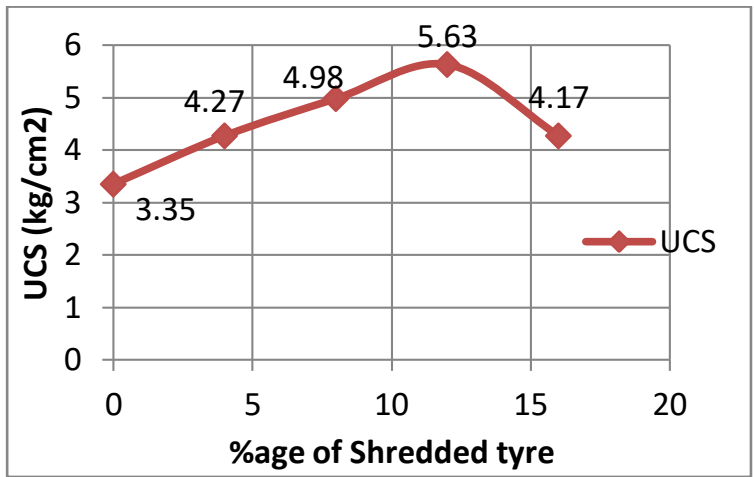

Fig-5 Variation of UCS with different \%age of shredded tyre

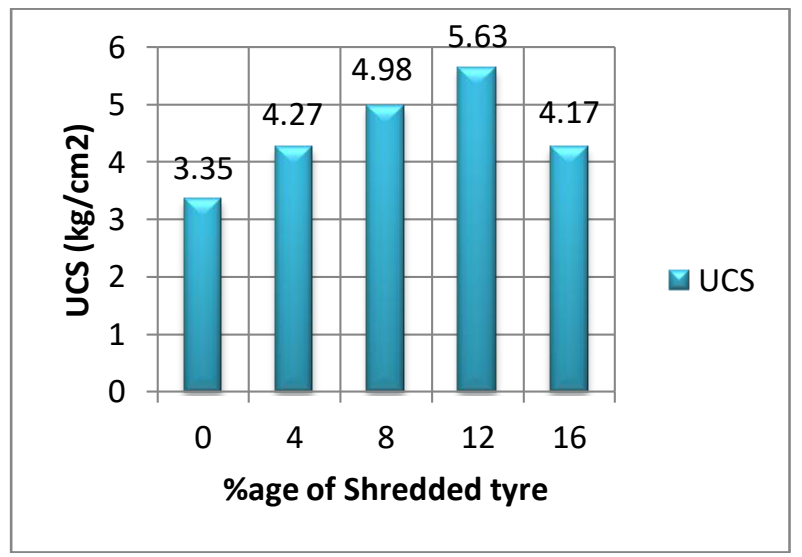

Fig-6 Bar Chart variation of UCS with different \%age of shredded tyre

With addition of lime treated shredded tyre in soil, the value of UCS increases from $3.35 \mathrm{~kg} / \mathrm{cm}^{2}$ to 5.63 $\mathrm{kg} / \mathrm{cm}^{2}$ up to $12 \%$ addition of shredded tyre, beyond that the value of UCS decreases as shown above in figure $5 \& 6$.

\subsubsection{California Bearing Ratio (CBR) Test}

\section{Un-soaked CBR}

A series of un-soaked California Bearing Ratio Tests are conducted on natural soil reinforced with varying percentages of shredded tyre $(4 \%, 8 \%, 12 \%$ and $16 \%)$ and Constant percentage of lime (10\%). CBR value with different percentage of shredded tyre under un-soaked condition is tabulated below. 
Table-6 Un-soaked CBR test result of reinforced soil

\begin{tabular}{|c|c|c|c|c|}
\hline Nomenclature & $\begin{array}{l}\text { Soil } \\
(\%)\end{array}$ & $\begin{array}{c}\text { Fixed } \\
\text { Lime } \\
(\%)\end{array}$ & $\begin{array}{c}\text { LTST } \\
(\%)\end{array}$ & $\begin{array}{c}\text { Un- } \\
\text { soaked } \\
\text { CBR } \\
(\%)\end{array}$ \\
\hline SL0T0 & 100 & 0 & 0 & 3.89 \\
\hline SL10T4 & 86 & \multirow{4}{*}{10} & 4 & 5.69 \\
\hline SL10T8 & 82 & & 8 & 7.94 \\
\hline SL10T12 & 78 & & 12 & 10.65 \\
\hline SL10T16 & 74 & & 16 & 8.47 \\
\hline
\end{tabular}

Based on the data from the California bearing ratio tests as presented in Table 6, it is inferred that CBR value for natural soil is observed to be $3.89 \%$ and is increased to $5.69 \%$ with an increment of about $46.27 \%$ for $4 \%$ tyre chips and constant $10 \%$ lime. CBR value is further increased to $7.94 \%$ for $8 \%$ tyre chips and $10 \%$ lime with an increment of about $104.1 \%$ comparing with CBR value of natural soil. If the percentage of shredded tyre is further increased to $12 \%$ then the CBR value also increased to $10.65 \%$ with an increment of about $173.8 \%$ compared to natural soil. With further increase in percentage of tyre chips to $16 \%$, CBR value is decreased. It is clearly observed that, addition of tyre chips and lime to the soil increases CBR value (As shown in Fig 7). This implies thickness of sub grade can be reduced with the addition of shredded tyre and lime. The reduction in pavement thickness directly implies the reduction in cost of the construction of pavement. Increase in CBR value for reinforced soil with increase of shredded tyre and lime is due to the fact that, the void space in the soil mass is filled up with tyre chips and lime and it offers higher resistance to the applied load due rebound nature of tyre.

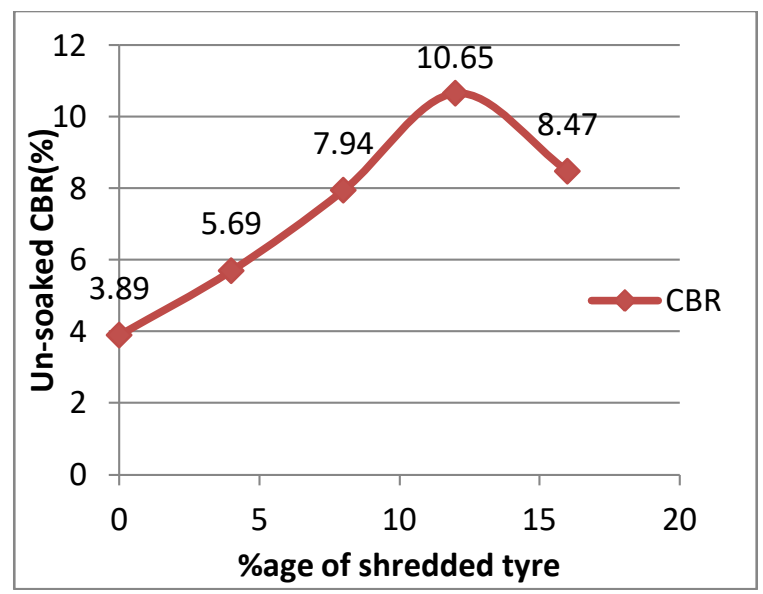

Fig- 7 Variation of Un-soaked CBR with different \%age of shredded tyre

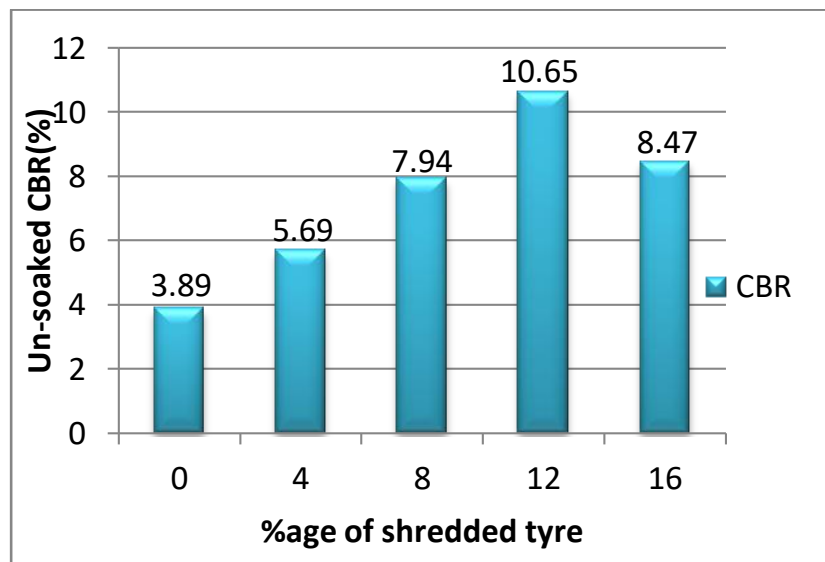

Fig- 8 Bar chart variation of Un-soaked CBR with different \%age of shredded tyre

\section{Soaked CBR test}

The value of CBR Test results in soaked Condition with different percentage of shredded tyre, obtained from experiments have been tabulated as

Table-7 Soaked CBR test result

\begin{tabular}{|c|c|c|c|c|}
\hline Nomenclature & $\begin{array}{l}\text { Soil } \\
(\%)\end{array}$ & $\begin{array}{c}\text { Fixed } \\
\text { lime } \\
(\%)\end{array}$ & $\begin{array}{l}\text { Tyre } \\
(\%)\end{array}$ & $\begin{array}{c}\text { Soaked } \\
\text { CBR } \\
(\%)\end{array}$ \\
\hline SL0T0 & 100 & 0 & 0 & 1.93 \\
\hline SL10T4 & 86 & \multirow{4}{*}{10} & 4 & 3.37 \\
\hline SL10T8 & 82 & & 8 & 4.63 \\
\hline SL10T12 & 78 & & 12 & 6.84 \\
\hline SL10T16 & 74 & & 16 & 3.48 \\
\hline
\end{tabular}

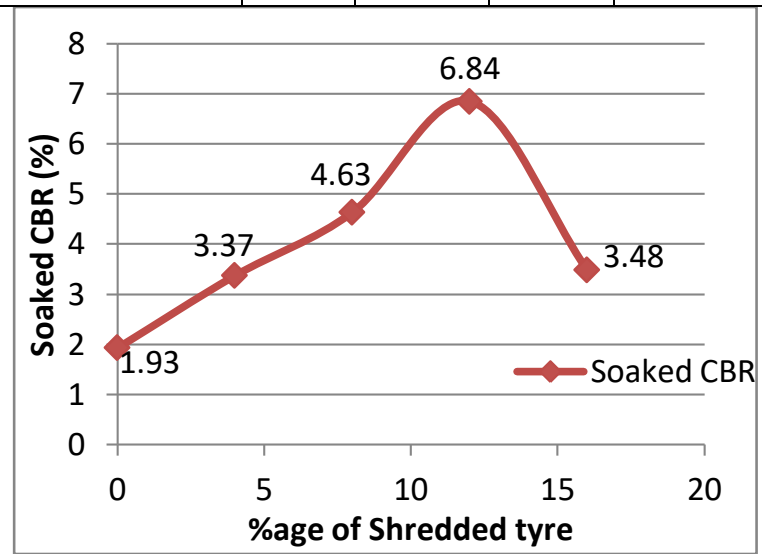

Fig-9 Variation of soaked CBR With different \%age of shredded tyre 


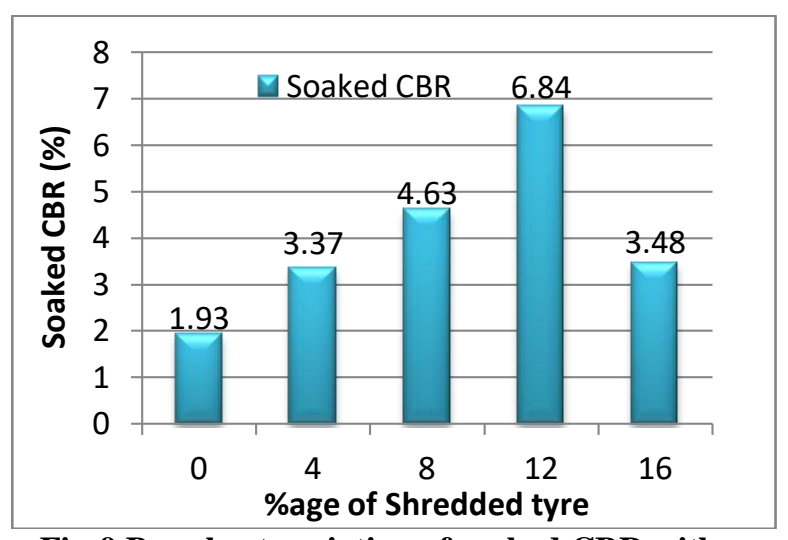

Fig-9 Bar chart variation of soaked CBR with different \%age of shredded tyre

With addition of shredded tyre the value of soaked CBR increases from $1.93 \%$ to $6.84 \%$ up to $12 \%$ addition of shredded tyre and constant percentage of lime (10\%) beyond that the value of soaked CBR value decreases as shown above in bar chart.

\subsubsection{Comparison of Soaked and Un-soaked CBR test results}

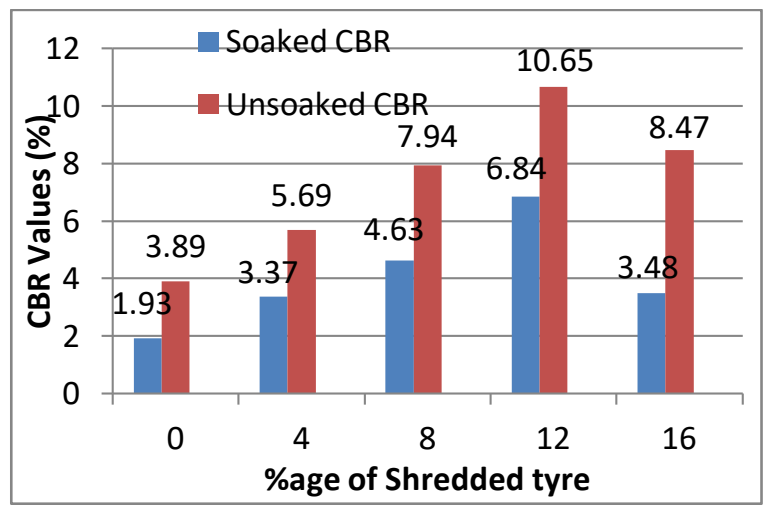

\section{Conclusions}

As per the data and results obtained from the experimental work on soil stability investigation with shredded tyre using lime of clayey soils with different percentages of shredded tyre i.e. $(4 \%, 8 \%$, $12 \%$ and $16 \%$ ) and fixed percentage of lime i.e. $(10 \%)$, the following conclusions can be drawn in the aspect of strength properties due to application of shredded tyre and lime as a reinforcing and binding material respectively for the natural soil.

Based on the results and discussions from the standard proctor test, it can be stated that with increase in percentage of shredded tyre and fixed percentage of lime, the compaction parameters (MDD, OMC) are also increased. From the above data, the maximum dry densities are found to be 1.80 $\mathrm{g} / \mathrm{cc}$ for $4 \%, 1.85 \mathrm{~g} / \mathrm{cc}$ for $8 \%, 1.93 \mathrm{~g} / \mathrm{cc}$ for $12 \%$ and $1.79 \mathrm{~g} / \mathrm{cc}$ for $16 \%$ of shredded tyre and fixed percentage of lime(10\%). This shows an increasing trend in MDD up to $12 \%$ of shredded tyre. It is also observed that there is a decreasing trend in OMC with increase in percentage of shredded tyre and constant lime percentage. So it is concluded that for effective soil stabilization $12 \%$ shredded tyre and $10 \%$ lime gives better results.

Based on UCS test result and discussions the value of unconfined compressive strength has increased from $3.35 \mathrm{~kg} / \mathrm{cm}^{2}$ to $5.63 \mathrm{~kg} / \mathrm{cm}^{2}$ corresponding to $12 \%$ of shredded tyre and $10 \%$ of lime.

Based on Un-soaked CBR test results and discussions, it is observed that addition of shredded tyre and lime as stabilizing agent for clayey soils produces significant increase in CBR value. It is concluded that, with increase in shredded tyre and for constant lime percentage, the CBR values are also increased considerably and un-soaked CBR value is found to be maximum $10.65 \%$ for $12 \%$ shredded tyre.

Based on soaked CBR test results and discussions, it is observed that addition of shredded tyre and lime as stabilizing agent for clayey soils produces significant increase in $\mathrm{CBR}$ value and soaked $\mathrm{CBR}$ value is found to be maximum $6.84 \%$ for $12 \%$ shredded tyre. From the above discussions, it is concluded that addition of shredded tyre and lime to the clayey soil there is considerable effect on the compaction parameters and bearing capacity of the soil. It is also concluded that, expensive methods for stabilization of soils such as with cement, fly ash etc. can be replaced together with shredded tyre and lime as an alternative method to improve the weak clayey soil properties. Shredded Tyre and lime can be used for stabilization of embankments, pavement sub-grade and other fields of civil engineering as per needs for clayey soil

\section{References}

[1] Kaushik and Mahato, Soil improvement by waste rubber tyre. International Research Journal of Engineering and Technology, Vol.04 (Issue 07): Pages 458-469, (2017)

[2] Umarjan and Sonthawal, Soil stabilization using shredded rubber tyre. International Research Journal of Engineering and Technology, Vol.02 (Issue 09): Pages 741-744, (2015).

[3] Firat and Karabash, Stabilization of clay using tyre buffings and lime. Road materials and pavement design, Vol.15 (Issue 04): Pages 872-891, (2014)

[4] Prasad and Ravichandran, Study on effect of crumb rubber on behavior of soil. International journal of geometrics and geosciences, Vol.04( Issue 03): Pages 579-584, (2014). 
[5] Hambirao and Rakaraddi, Soil Stabilization Using Waste Shredded Rubber Tire Chips. Journal of Mechanical and Civil Engineering, Vol.11(Issue 01): Pages 20-27, (2014).

[6] Ayothiraman and Meena, Improvement of Sub grade soil with shredded waste tyre chips. Proceedings of Indian Geotechnical Conference, Vol. 15( Issue 17): Pages 365-368,(2011).
[7] J Foose and J Bosscher, Sand Reinforced with shredded waste Tires. Journals of Geotechnical Engineering,Vol.122(Issue08):Pages760-767, (1996)

[8] Humphrey, Civil engineering applications of tire shreds. Proceedings of the Tire Industry Conference, Vol.7 (Issue 05): Pages 1-16, (1999).. 